\title{
Cyclic voltammetry characterization analysis on the CU/flame retardant 4 fabricated biosensor
}

\author{
Irni Hamiza Hamzah', Azman Ab Malik², Aida Zulia Zulhanip ${ }^{3}$, Zainal Hisham Che Soh ${ }^{4}$, \\ Alhan Farhanah Abd Rahim ${ }^{5}$ \\ ${ }^{1,3,4,5}$ Faculty of Electrical Engineering, Universiti Teknologi MARA, Malaysia \\ ${ }^{2}$ School of Engineering, Penang Skills Development Centre, Malaysia
}

\begin{tabular}{l}
\hline Article Info \\
\hline Article history: \\
Received Jul 28, 2019 \\
Revised Oct 29, 2019 \\
Accepted Nov 13, 2019 \\
\hline
\end{tabular}

\section{Keywords:}

Cyclic voltammetry

Electrodes

FR4

Label free biosensor

Reversible

\begin{abstract}
Silicon, glass and ceramic are commonly base substrate used in DNA biosensor fabrication due to its biocompatible, expensive, hard and brittle. However due to the difficulty for drilling and dicing, these materials required expensive equipments and complex methodology of fabrication. Large gap of thermal expansion coefficient (TEC) between silicon/glass and film caused microcracks. Hence, the aim of this work is to investigate the suitability and the application of a non-biocompatible material, flame retardant 4 (FR4) as a base substrate for a label free DNA biosensor. Cyclic voltammetry (CV) reversible method has been implemented to test the fabricated $\mathrm{Cu} / \mathrm{Au}$ on the FR4. It is found that the fabrication of $\mathrm{Au}$ has been made possible by the used of oxide-free $\mathrm{Cu}$ as an adhesion layer on the FR4 substrate. The area size of counter electrode (CE), working electrode (WE) and reference electrode (RE) are found to be $6.25 \mathrm{~mm} 2,0.581 \mathrm{~mm} 2$ and $1.04 \mathrm{~mm} 2$, respectively, in order to achieve the unity reversible redox relationship and to ensure the sensor's reliability for $10 \mathrm{mM} \mathrm{K} 3 \mathrm{Fe}(\mathrm{CN}) 6$ solution in $0.1 \mathrm{M} \mathrm{KCl}$. Thus it can be concluded that the proposed FR4-based substrate fulfilled the $\mathrm{CV}$ reversible process characterization.
\end{abstract}

Copyright $\odot 2020$ Institute of Advanced Engineering and Science. All rights reserved.

\section{Corresponding Author:}

Irni Hamiza Hamzah,

Faculty of Electrical Engineering,

Universiti Teknologi MARA,

Cawangan Pulau Pinang, 13500, Malaysia.

Email: irnihami@ppinang.uitm.edu.my

\section{INTRODUCTION}

SU8 film fabrication on silicon or glass are biocompatible substrates that has been widely reported [1] but the large gap of thermal expansion coefficients (TEC) between silicon/glass and SU8 in which TEC of silicon is $3.2 \mathrm{ppm} /{ }^{\circ} \mathrm{C}$ [2], glass plate is $8.6 \mathrm{ppm} /{ }^{\circ} \mathrm{C}$ [3] and SU8 is $52 \mathrm{ppm} /{ }^{\circ} \mathrm{C}$ [4] caused microcracks on SU8 fabricated on silicon/glass [5]. The characteristic of silicon or glass which is hard and brittle made it difficult for drilling and dicing thus required complex equipments such as deep reactive ion etching (DRIE) and diamond-coated cutter for dicing. Therefore, the objective in this work is to study the suitability of non-biocompatible material, Flame Retardant 4 (FR4) for gold (Au) fabrication using thermal evaporator and wet etching techniques throughout all conducting tracks from sensing layer to terminal layer.

Electrochemical biosensors methodology has been the focused in this work due to its fast response time compared to piezoelectric biosensors [6] and the sensitivity is better when miniaturized compared to optical biosensors [7]. Electrochemical biosensors can be classified into amperometric (current measured); potentiometric (voltage measured); impedance (resistance and capacitance measured) and conductometric (conductivity measured). 


\section{RESEARCH METHOD}

In this work, a $2 \mathrm{~cm}$ length, $1.2 \mathrm{~cm}$ width and $1.6 \mathrm{~mm}$ thickness of FR4 was used as a base material. The FR4 was cleaned sequentially with acetone and isopropanol then left to dry with nitrogen gas. Original native oxidized-free copper $(\mathrm{Cu})$ on FR4 has been immersed in acetic acid at $35^{\circ} \mathrm{C}$ for 5 to 10 minutes until a shiny copper surface without streaking or hazy residue was observed. Upon removal, the samples were subsequently dried with nitrogen.

The $99.99 \%$ gold $(\mathrm{Au})$ of $0.3 \mathrm{~g}$ is evaporated directly to this $\mathrm{Cu} / \mathrm{FR} 4$ using a thermal evaporator of $6.0 \times 10-5$ mbar pressure at 68A and performed $1 \mu \mathrm{m} \mathrm{Au}$ electrode layer. Further investigation under SEM image analysis proved that the above mentioned method is effective to remove $\mathrm{Cu}$ oxide layer. Figure 1 reflects the SEM image of 900 magnification for the $\mathrm{Au}$ deposited on the $\mathrm{Cu}$ which was free from oxide layer. SEM image in Figure 1 is being analysed using EDX in order to determine the elemental compositions on the layers. The EDX profile of Figures 2, 3 and 4 magnify the SEM image to 9000 magnification and list all the elements for 3 different spots.

Figure 2 of spot 1 indicates that the layer consists of Carbon $(C)$, Oxygen $(\mathrm{O})$, Aluminium (Al), Silicon ( $\mathrm{Si}$ ) and $\mathrm{Au}$. Figure 3 of spot 2 indicates that the layer consists of C, O, Al, Si, Calcium (Ca) and Au. Figure 4 of spot 3 indicates that the layer consists of $\mathrm{Ca}, \mathrm{C}, \mathrm{O}, \mathrm{Cu}, \mathrm{Al}$ and $\mathrm{Si}$. The existence of $\mathrm{C}, \mathrm{O}, \mathrm{Al}, \mathrm{Ca}$ and $\mathrm{Si}$ are due to the epoxy and grinding process that are used for the fabricated $\mathrm{Cu} / \mathrm{Si}$ on FR4-based. From the SEM/EDX results, it is concluded that spot 1 and spot 2 contained mainly Au while spot 3 contained mainly $\mathrm{Cu}$.

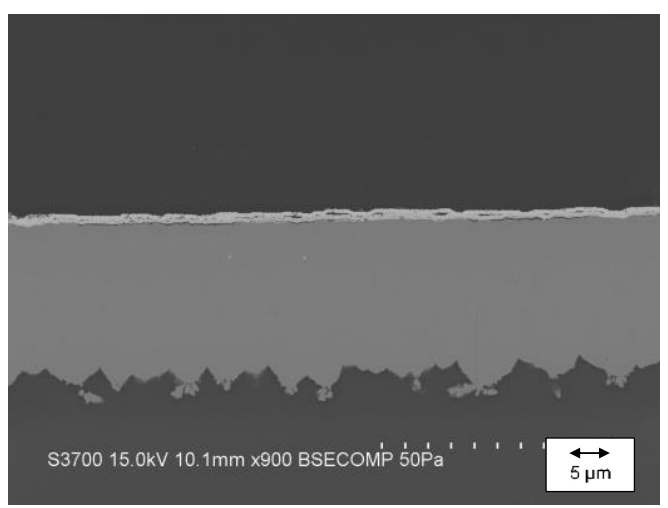

Figure 1. SEM image on the quality of Au deposited on $\mathrm{Cu}$ which was free from oxide layer
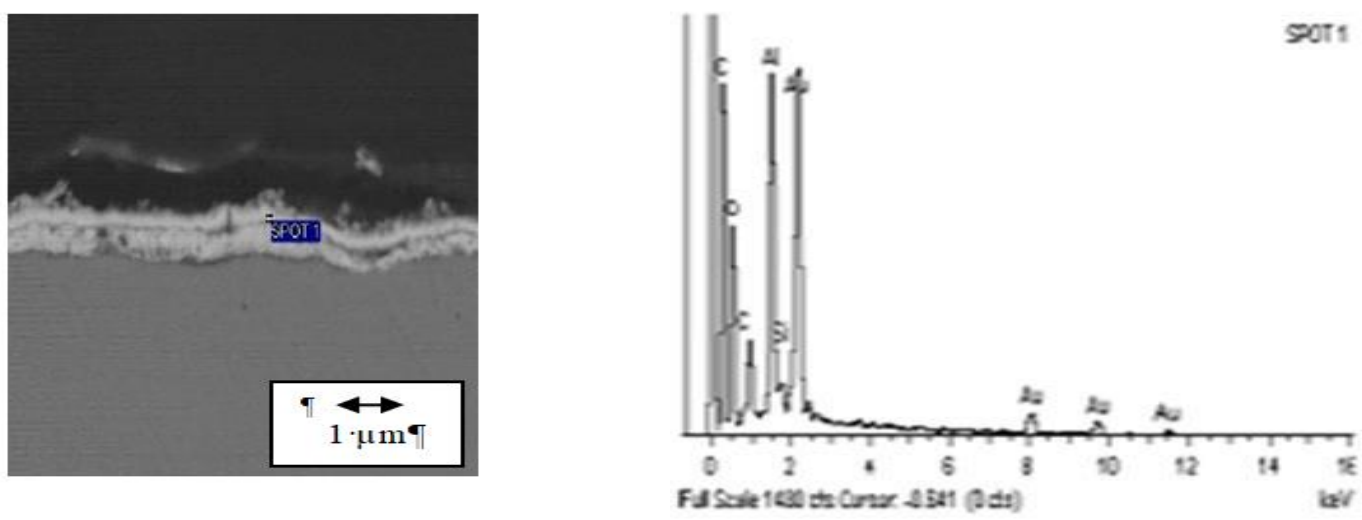

Figure 2. SEM image and EDX profile for spot 1. (a) SEM image. (b) EDX profile

The $\mathrm{Cu} / \mathrm{Au}$ on FR4-based sensor was designed with the areas of counter electrode (CE), working electrode (WE), and reference electrode were $6.25 \mathrm{~mm} 2,0.581 \mathrm{~mm} 2$ and $1.04 \mathrm{~mm} 2$, respectively, as shown in Figure 5 in order to fulfill the suggestion of [8] for the surface area ratio of CE to WE should be larger than 10 in order to sufficiently support the current generated at the WE. 

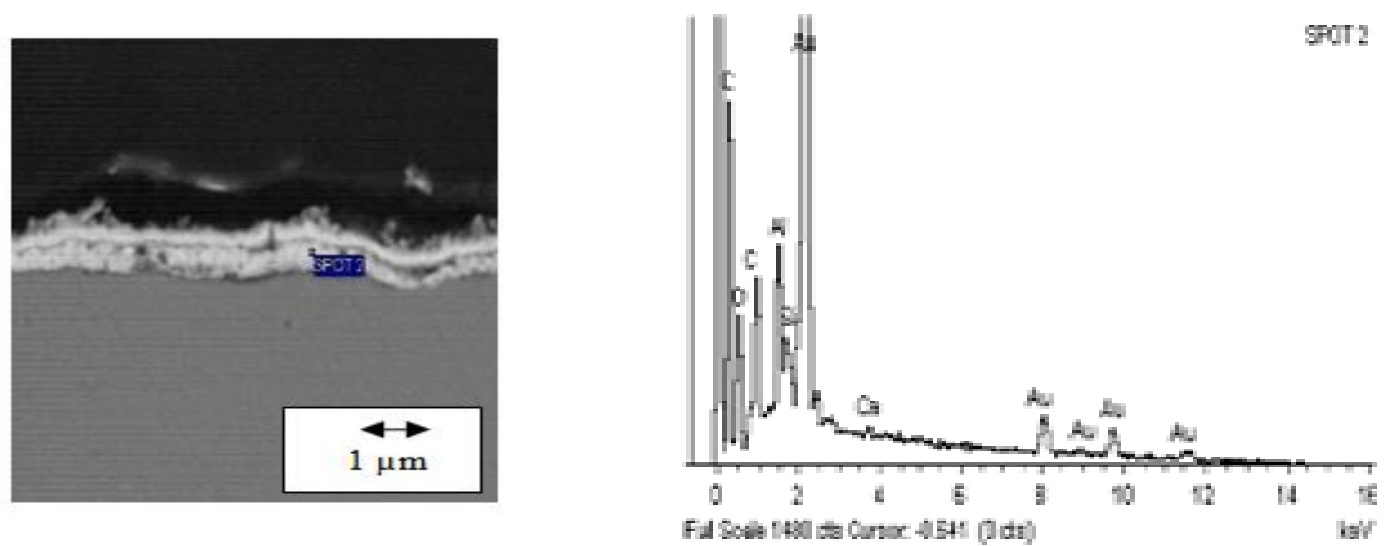

Figure 3. SEM image and EDX profile for spot 2. (a) SEM image. (b) EDX profile
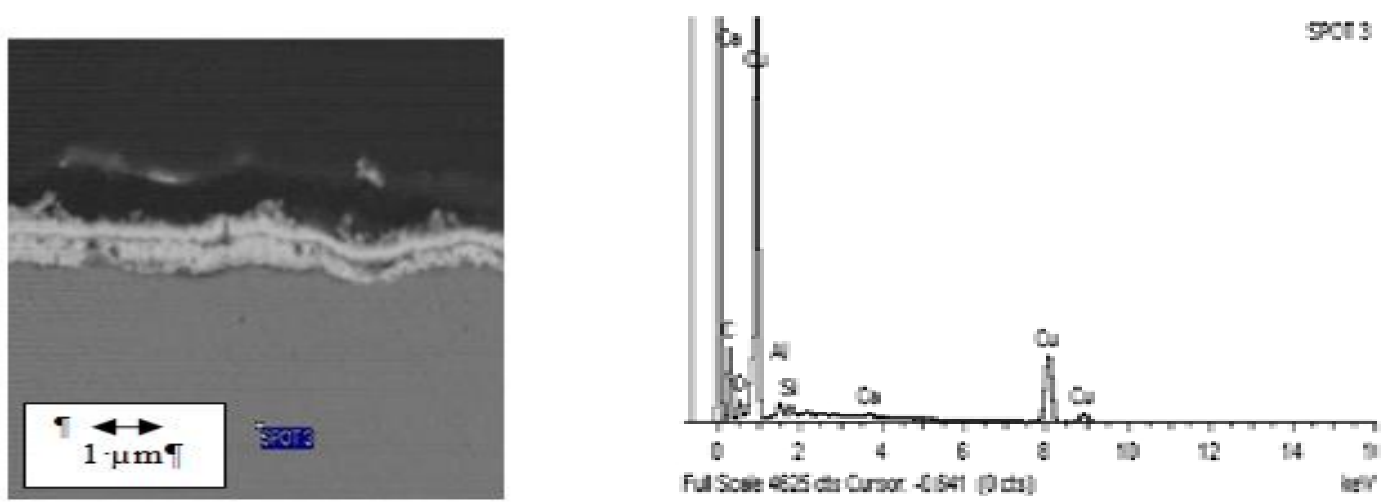

Figure 4. SEM image and EDX profile for spot 3. (a) SEM image. (b) EDX profile
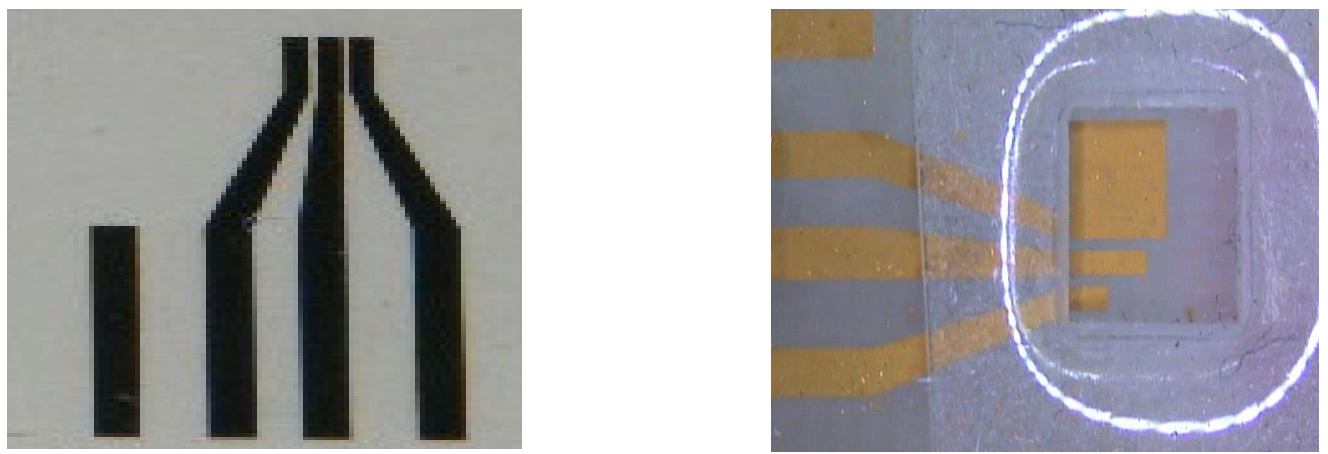

Figure 5. A new design with the area size of CE to WE ratio was 10:1. (a) the mask. (b) the actual fabricated $\mathrm{Cu} / \mathrm{Au}$ electrode

\section{RESULTS AND ANALYSIS}

The reliability test has been conducted to observe the sensor's performance in producing the oxidation and reduction peak of currents in the range of $-0.5 \mathrm{~V}$ to $+0.5 \mathrm{~V}$ with a fixed scan rate of $100 \mathrm{mV} / \mathrm{s}$ using $10 \mathrm{mM} \mathrm{K} 3 \mathrm{Fe}(\mathrm{CN}) 6$ solution in $0.1 \mathrm{M} \mathrm{KCl}$.

\subsection{Peak Potential Separation}

A peak potential separation was described as, 


$$
\Delta E_{p}=E_{p a}-E_{p c} \approx 59.2 / \mathrm{n} \mathrm{mV} \text { at } 25 \circ \mathrm{CC}
$$

where $\boldsymbol{E}_{p a}$ is the anodic peak potential (in $\mathrm{mV}$ ), $\boldsymbol{E}_{p c}$ is the cathodic peak potential (in $\mathrm{mV}$ ) and $\mathrm{n}$ is the number of electrons transferred in a reversible system.

From (1), the number of electrons involved in a reversible system can be determined. Table 1 lists the peak potential separation and number of electrons involved in a reversible system. It can be concluded from Table 1 that for the first cycle up to the 8th cycle, the number of electrons transferred was 1 . In common practice, the DNA biosensor will be used only once for bare Au measurement and thus it can be concluded that the proposed FR4-based substrate fulfilled (1). Further analysis on the same sensor until 21st cycles was shown in Figure 6. It is observed that the value on the peak oxidation potential and peak reduction potential also increased with the increasing cycles. This happened due to the formation of passivating layer known as prussian blue (KFe4III[Fe2II $(\mathrm{CN}) 6])$. The layer may deposit on the electrode surface during the cyclic voltammetry experiment [9-12]. The existence of this layer decreased the rate of electron transfer, therefore, more value of oxidation potential as well as reduction potential were needed to free the electrons [13-15].

Table 1. Peak Potential Separation and Number of Electrons Transferred for Scan Rate of $100 \mathrm{mV} / \mathrm{s}$

\begin{tabular}{lllll}
\hline Cycle & $\begin{array}{l}\text { Peak oxidation potential } \\
E_{p a}\end{array}$ & $\begin{array}{l}\text { Peak reduction potential } \\
E_{p c}\end{array}$ & $\begin{array}{l}\text { Separation } \\
\text { peak potential } \\
E_{p a}-E_{p c}\end{array}$ & $\begin{array}{l}\text { Number of } \\
\text { electrons transferred, } n\end{array}$ \\
\hline 1 & 0.317841 & 0.251923 & 0.061036 & 1.0 \\
2 & 0.317841 & 0.261688 & 0.056153 & $1.1 \cong 1$ \\
3 & 0.317841 & 0.261688 & 0.056153 & $1.1 \cong 1$ \\
4 & 0.315399 & 0.264130 & 0.051269 & $1.2 \cong 1$ \\
5 & 0.322723 & 0.276337 & 0.046386 & $1.3 \cong 1$ \\
6 & 0.342255 & 0.295868 & 0.046387 & $1.3 \cong 1$ \\
7 & 0.352020 & 0.300751 & 0.051269 & $1.2 \cong 1$ \\
8 & 0.354462 & 0.308075 & 0.046387 & $1.3 \cong 1$ \\
\hline
\end{tabular}

\subsection{Peak Current Ratios}

The CV data analysis obtained from Figure 6 has been listed in Table 2. It is noticed that the FR4based sensor produced the peak current ratio nearly to unity up to the 3 rd cycle. Then, the peak current ratio increased with the increasing cycles. In the range of $-0.5 \mathrm{~V}$ to $+0.5 \mathrm{~V}$, the $\mathrm{CV}$ graphs performed the obvious anodic peak current only until the 8th cycle. Therefore, the anodic and cathodic peak currents can only been analyzed until the 8th cycle. For more than 3rd cycle, the peak current ratios greater than unity due to the product (ferrocyanide) which was weakly adsorbed on the electrode and thus, the anodic peak currents were enhanced dramatically whereas the cathodic peak currents showed a small increase [16-18].

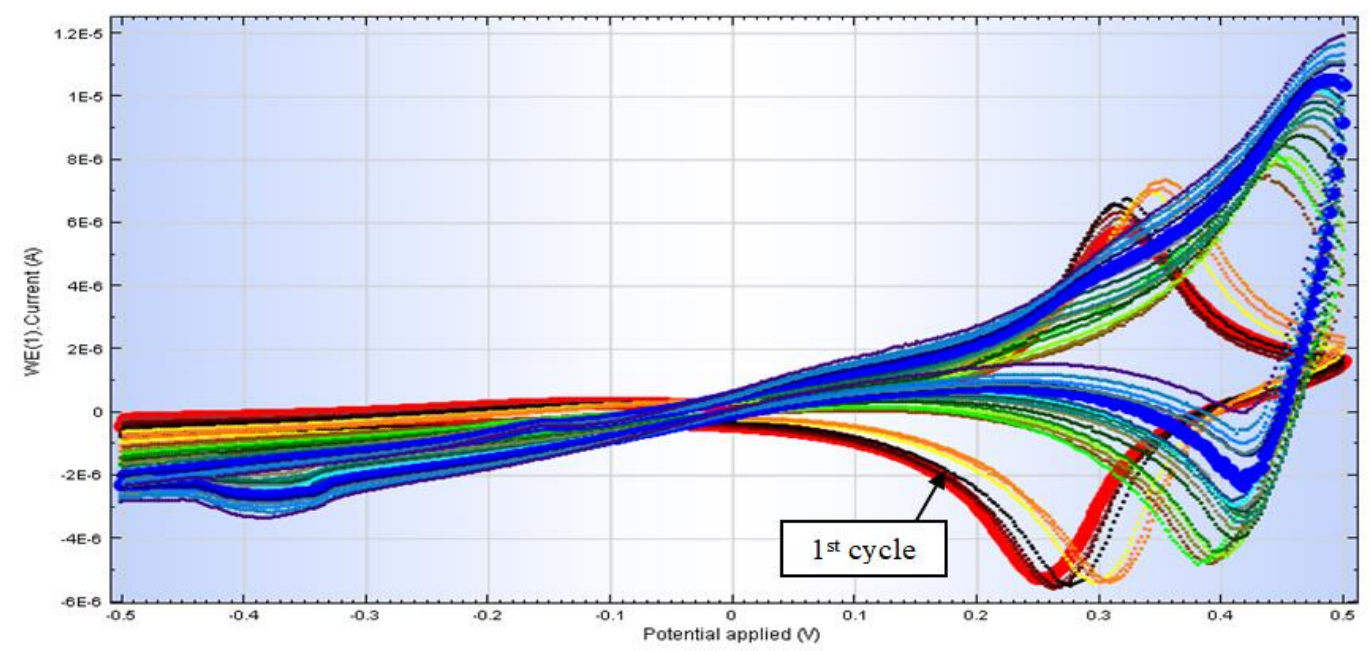

Figure 6. Sensor's reliability test until 21 st cycles. 
Table 2. Anodic Peak Current, Cathodic Peak Current and Peak Current Ratio for Scan Rate of $100 \mathrm{mV} / \mathrm{s}$

\begin{tabular}{cccc}
\hline Cycle & Anodic Peak Current & Cathodic Peak Current & Peak Current Ratio \\
& $I_{\mathrm{pa}}$ & $I_{\mathrm{pc}}$ & $I_{p a} / I_{p c}$ \\
\hline 1 & 3.95 & 3.88 & 1.02 \\
2 & 4.34 & 4.16 & 1.04 \\
3 & 4.48 & 4.25 & 1.05 \\
4 & 4.72 & 4.33 & 1.09 \\
5 & 5.03 & 4.36 & 1.15 \\
6 & 5.13 & 4.40 & 1.17 \\
7 & 5.06 & 4.34 & 1.17 \\
8 & 5.37 & 4.52 & 1.19 \\
\hline
\end{tabular}

\subsection{Peak Current Function}

Based on [17] as in (2),

$$
\mathrm{Ip}=(2.69 \times 105) \mathrm{n} 3 / 2 \mathrm{~A} \text { D } 1 / 2 \mathrm{C} \text { v1/2 }
$$

where Ip is the peak current (in ampere), $\mathrm{n}$ is the electron stoichiometry, $\mathrm{A}$ is the electrode area (in centimeter square), D is the diffusion coefficient (in centimeter square per second), $\mathrm{C}$ is the concentration of the electroactive species (in moles per centimeter cubic) and $\mathrm{v}$ is the scan rate (in volts per second). The parameters of A (electrode area), $\mathrm{n}$ (electron stoichiometry), $\mathrm{C}$ (concentration of the electroactive species) and D (diffusion coefficient) were fixed, therefore the value of Ip was dependent to the square root parameter of $\mathrm{v}$ (scan rate) which varied in this analysis. The linear increase in peak currents with $\mathrm{v} 1 / 2$ indicates that the oxidation process is diffusion controlled [16, 19, 20].

Table 3 reflects all the peak current values different value of CV scan rates from $100 \mathrm{mV} / \mathrm{s}$ to $1 \mathrm{~V} / \mathrm{s}$ for the fabricated sensor. It showed that the anodic peak currents and cathodic peak currents will be increased with the increasing value on the scan rates. Thus, the results performed satisfied the Randle-Sevcik [21] equation. Figure 7 and Figure 8 show regression analysis using statistical software, SigmaPlot for Windows ver 11.0 for estimating the relationships among anodic peak currents and cathodic peak currents variables as in Table 3, respectively.

Table 3. Anodic Peak Current, Cathodic Peak Current and Peak Current Ratio for Different Value of Scan Rates

\begin{tabular}{ccccc}
\hline Scan rate & $v^{1 / 2}$ & Anodic peak current, $\mathrm{I}_{\mathrm{pa}}$ & Cathodic peak current, $\mathrm{I}_{\mathrm{pc}}$ & $\mathrm{I}_{\mathrm{pa}} / \mathrm{I}_{\mathrm{pc}}$ \\
\hline $100 \mathrm{mV} / \mathrm{s}$ & 0.3162 & 11.4535 & 11.2671 & 1.02 \\
$200 \mathrm{mV} / \mathrm{s}$ & 0.4472 & 16.1029 & 13.7081 & 1.17 \\
$300 \mathrm{mV} / \mathrm{s}$ & 0.5477 & 18.884 & 15.3752 & 1.23 \\
$400 \mathrm{mV} / \mathrm{s}$ & 0.6325 & 21.2455 & 16.8256 & 1.26 \\
$500 \mathrm{mV} / \mathrm{s}$ & 0.7071 & 23.3776 & 17.4269 & 1.34 \\
$600 \mathrm{mV} / \mathrm{s}$ & 0.7746 & 24.8812 & 18.2372 & 1.36 \\
$700 \mathrm{mV} / \mathrm{s}$ & 0.8367 & 26.416 & 19.4443 & 1.36 \\
$800 \mathrm{mV} / \mathrm{s}$ & 0.8944 & 27.8115 & 20.5226 & 1.36 \\
$900 \mathrm{mV} / \mathrm{s}$ & 0.9487 & 29.6635 & 21.2498 & 1.40 \\
$1 \mathrm{~V} / \mathrm{s}$ & 1 & 31.6662 & 22.5232 & 1.41 \\
\hline
\end{tabular}

Table 3 obviously indicates that the value of anodic peak currents increased dramatically as compared to the value of cathodic peak currents. The weak adsorption of product has little effect on the cathodic scan. This is due to the adsorption of product which required the electrode reaction to provide more material for both diffusion process and adsorption process; therefore the peak occurred at more anodic potentials, in analogy with the succeeding chemical reaction [16, 22-24].

Table 4 lists the linear curve coefficients, $\mathrm{f}=\mathrm{y} 0+\mathrm{a}^{*} \mathrm{x}$ and $\mathrm{R}$-squared values for Figure 7 and Figure 8. R-squared is a statistical term in predicting the value of another variable [25]. The R-squared value of 1.0 perfectly predicts the value of another variable. On the other hand, the R-squared value of 0.0 does not help to predict the other term at all. More generally, higher value of R-squared means better predictor of one term to another.

Table 4. Coefficients and R-Squared Values for Anodic and Cathodic Peak Currents Linear Curve Function

\begin{tabular}{cccc}
\hline $\mathrm{f}=\mathrm{y} 0+\mathrm{a}^{*} \mathrm{x}$ & $\mathrm{y} 0$ & $\mathrm{a}$ & $\mathrm{R}^{2}$ \\
\hline Fig. 10 & 3.1669 & 28.1252 & 0.9964 \\
Fig. 11 & 6.5700 & 15.6057 & 0.9939 \\
\hline
\end{tabular}




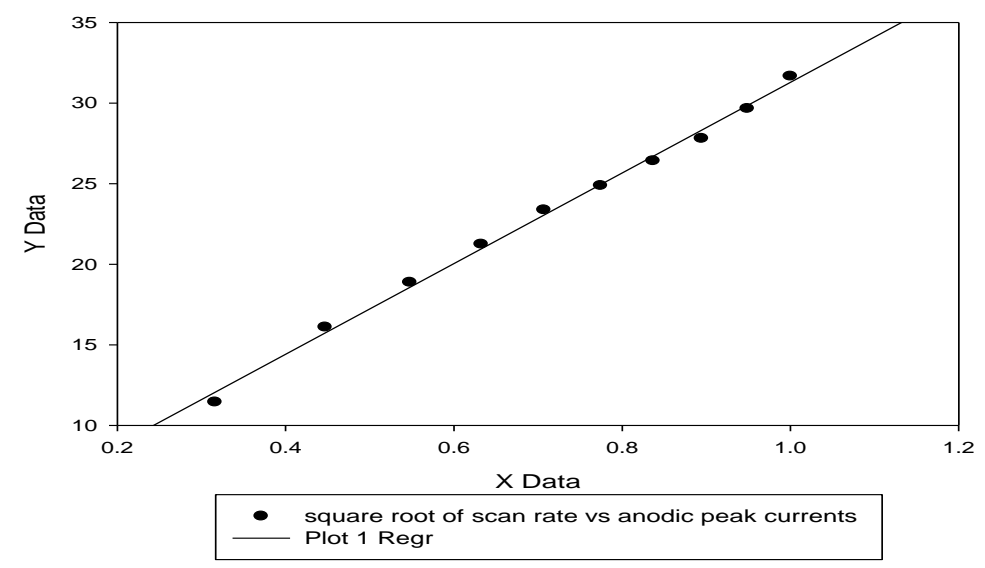

Figure 7. Simple scatter with regression for estimating anodic peak current variables

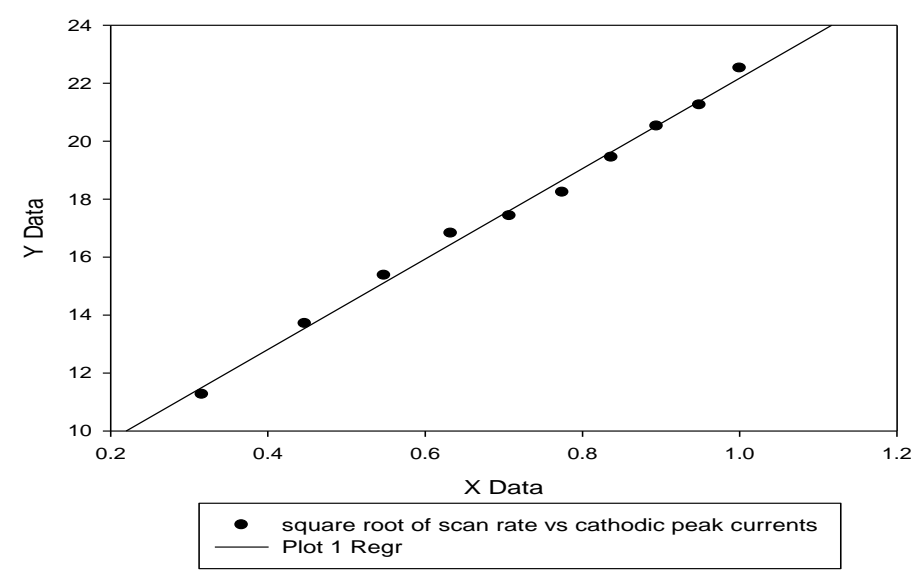

Figure 8. Simple scatter with regression for estimating cathodic peak current variables

A linear curve for anodic peak current and cathodic peak current proved that both peak currents can be represented in terms of square root of scan rate function. The R-squared value approaching unity reflected that both linear regressions can predict the value of peak currents by knowing the value for square root of scan rate. Thus, the sensor can be classified as able to perform the reversible process.

\section{CONCLUSION}

Three types of analysis were performed on the fabricated $\mathrm{Cu} / \mathrm{Au}$ FR4-based sensor to ensure its reliability and reversible redox activity were peak potential separation, peak current ratio and peak current function. All these analysis performed were based on the Randle-Sevcik equation. The results showed that for the first cycle up to the 8th cycle, the FR4-based sensor fulfilled the peak potential separation equation, the first cycle to the third cycle fulfilled the peak current ratio near to unity and a linear curve for both peak currents proved that the peak current can be represented in term of square root of scan rate function. In common practice, the DNA biosensor was used only once for bare Au measurement and thus it can be concluded that the proposed FR4-based substrate fulfilled the CV reversible process characterization. During these analysis, it was noted that the value on the peak voltages increased with the increasing cycles due to the formation of prussian blue.

\section{ACKNOWLEDGEMENTS}

This work is sponsored by the Ministry of Higher Education (MOHE) fund from Fundamental Research Grant Scheme (FRGS) with reference no FRGS/1/2018/TK0 4/UiTM/02/35. The financial support is gratefully appreciated. 


\section{REFERENCES}

[1] J. Ramirez, et al., "Low-loss modified SU-8 waveguides by direct laser writing at 405 nm," Opt. Mater. Express, vol. 7, pp. 2651-2659, 2017.

[2] H. Watanabe, N. Yamada, and M. Okaji, "Linear thermal expansion coefficient of silicon from 293 to $1000 \mathrm{~K}$," International Journal of Thermophysics, vol. 25, no. 1, pp. 221-236, 2004.

[3] Makishima and J. D. Mackenzie, "Calculation of thermal expansion coefficient of glasses," Journal of Non-Crystalline Solids, vol. 22, no. 2, pp. 305-313, 1976.

[4] N. Chronis and L. P. Lee, "Electrothermally activated SU-8 microgripper for single cell manipulation in solution," Journal of Microelectromechanical Systems, vol. 14, no. 14, pp. 857-863, 2005.

[5] Shamsi, et al., "Low cost method for hot embossing of microstructures on PMMA by SU-8 masters," Microsystem Technologies, vol. 20, no. 10-11, pp. 1925-1931, Oct 2014.

[6] P. Skládal, "Piezoelectric biosensors," TrAC Trends in Analytical Chemistry, vol. 79, pp. 127-133, May 2016.

[7] S. M. Yoo and S. Y. Lee, "Optical Biosensors for the Detection of Pathogenic Microorganisms," Trends in Biotechnology, vol. 34, no. 1, pp. 7-25, Jan 2016.

[8] C. M. A. Brett and A. M. O Brett, "Electrochemistry-principles, methods, and applications" Oxford Univ. Press, London, UK, pp. 185-186, 1993.

[9] Y. Huang, et al., "A Novel Border-Rich Prussin Blue Synthesized by Inhibitor Control as Cathode for Sodium Ion Batteries," Nano Energy, vol. 39, pp. 273-283, 2017.

[10] W. Ren, et al., "Activation of Sodium Storage Sites in Prussian Blue Analogues via Surface Etching," Nano Letters, vol. 17, no. 8, pp. 4713-4718, Jun 2017.

[11] C. M. Pharr and P. R. Griffiths, "Infrared Spectroelectrochemical Analysis of Adsorbed Hexacyanoferrate Species Formed during Potential Cycling in the Ferricyanide/Ferrocyanide Redox Couple" Anal. Chem., vol. 69, pp. 4673-4679, 1997.

[12] M. C. Granger and G. M. Swain "The influence of surface interactions on the reversibility of ferri/ferrocyanide at boron-doped diamond thin-film electrodes" J. Electrochem. Soc., vol. 146, pp. 4551-4558, 1999.

[13] K. Mahmood, S. Sarwar and M. T. Mehran, "Current status of electron transport layers in perovskite solar cells: materials and properties," RSC Advances, vol. 7, no. 28, pp. 17044-17062, 2017.

[14] U. K. Thakur, R. Kisslinger and K. Shankar, "One-Dimensional Electron Transport Layers for Perovskite Solar Cells," Nanomaterials, vol. 7, no. 5, pp. 95, May 2017.

[15] S. K. Fernandes, et al., "Exploring the Properties of Niobium Oxide Films for Electron Transport Layers in Perovskite Solar Cells," Front. Chem., Feb 2019.

[16] R. H. Wopschall and I. Shain, "Effects of adsorption of electroactive species in stationary electrode polarography," Analytical Chemistry, vol. 39, no. 13, Pages 1514-1527, 1966.

[17] N. Elgrishi et. al., "A Practical Beginner's Guide to Cyclic Voltammetry," Journal of Chemical Education, vol. 95 , no. 2, pp. 197-206, 2018.

[18] E. M. Espinoza, et. al., "Practical Aspects of Cyclic Voltammetry: How to Estimate Reduction Potentials When Irreversibility Prevails," Journal of The Electrochemical Society, vol. 166, no. 5, pp. 3175-3187, 2019.

[19] H. C. Yang, et al., "Polydopamine gradients by oxygen diffusion controlled autoxidation," Chemical Communications, vol. 49, pp. 10522-10524, 2013.

[20] $\mathrm{H}$. Wu, et al., "Stable cycling of double-walled silicon nanotube battery anodes through solid-electrolyte interphase control," Nature Nanotechnology, vol. 7, pp. 310-315, 2012.

[21] J. Bard and L. R. Faulkner, "Electrochemical methods-fundamentals and applications" Wiley \& Sons: New York, p. 566, 2001

[22] S. Shahrokhian, et al., "Voltammetric Behavior and Determination of Trace Amounts of Omeprazole Using an Edge-plane Pyrolytic Graphite Electrode," Iranian J. Pharm Res., vol. 14, no. 2, pp. 465-471, 2015.

[23] L. Rajic, et al., "The influence of cathode material on electrochemical degradation of trichloroethylene in aqueous solution," Chemosphere, vol. 147, pp. 98-104, Mar 2016.

[24] H. Wang et al., "Effect of Alternating Current on the Cathodic Protection and Interface Structure of X80 Steel," Materials, vol. 10, no. 8, pp. 851, Aug 2017.

[25] S. N. Wood, Generalized Additive Models: An Introduction with R, 2nd Edition, Chapman and Hall, New York, 2017.

\section{BIOGRAPHIES OF AUTHORS}

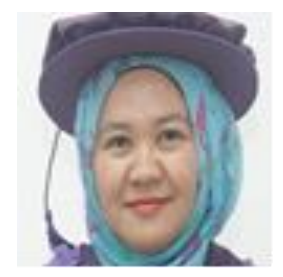

Irni Hamiza Hamzah was born in Machang, Kelantan on 6th December 1974. She obtained her B. Eng (Hons) in Electrical and Electronic Engineering in 1998, MSc. Electronics System and Design Engineering in 2005 and PhD in BioMEMs Sensors in 2013, which all had been obtained from School of of Electrical and Electronic Engineering, Universiti Sains Malaysia, Malaysia. She is currently a Senior Lecturer in Electronic Engineering Department, Faculty of Electrical Engineering, Universiti Teknologi MARA, Penang Branch Campus, Malaysia. Her research interests include Biosensors, BioMEMs, Neural Networks and Renewable Energy. She is a Chartered Engineer and a Corporate Member of Institute of Engineer's Malaysia (IEM). 


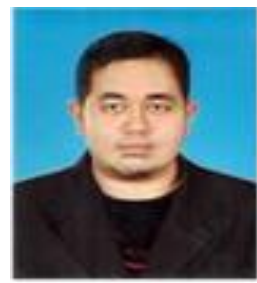

Azman Ab Malik Azman Ab Malik was born in Melaka on 12 October 2018. He obtained his Diploma in Electronic Technology from KKTM Pasir Mas in 2007, Bachelor in Electrical Engineering and Technology from UNIKL BMI, Master in Electrical and Electronic Engineering from USM and Phd in Electrical Engineering from UITM. His interest in innovation towards electrical and electronic and cross multi-disciplinary area to identify a new model or method in engineering. His research interest include electrical power, power system, renewable energy, hybrid system, embedded system, wireless power transfer and energy storage. He is currently a Senior Lecturer in School of engineering, Penang Skill Development Centre, Pulau Pinang Malaysia.

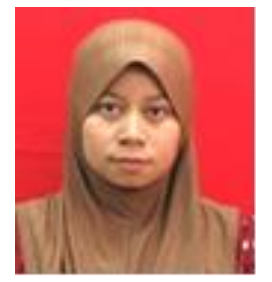

Aida Zulia Zulhanip received her B. Engineering (Hons) (Electrical) in 2008 from UiTM, Malaysia and Master of Engineering (Electrical-Electronics and Telecommunications) in 2011 from UTM, Malaysia. She is currently a Senior Lecturer in Electronic Engineering Department, Faculty of Electrical Engineering, UiTM, Penang Branch Campus. Her research interests include audio engineering (acoustic), big data, communication and sensor networks.

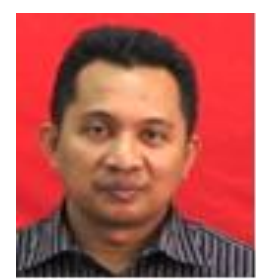

Zainal Hisham Che Soh was born in Machang, Kelantan on 16th March 1974. He obtained his B. Eng (Hons) in Electronic Engineering from University of Leeds, UK in 1997, MSc. in Computer Science in Real-Time Software Engineering from UTM in 2004 and PhD in Electrical and Electronic from USM in 2013. His research interest in Internet of Things, Big Data, Distributed/Parallel Computing, Artificial Intelligence, Microcontroller System and Wireless Sensor Network. He works in UiTM Pulau Pinang under Faculty of Electrical Engineering, UiTM, Pulau Pinang. He is a member of IEE, IET, BEM and MySEIG

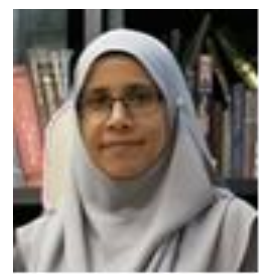

Alhan Farhanah Abd Rahim obtained her B.Eng Hons in Electronics Engineering from University of Southampton in 1998, MSc and PhD in Solid State Physics from Universiti Sains Malaysia in 2003 and 2014 respectively. She is currently senior lecturer at the Faculty of Electrical Engineering, Universiti Teknologi MARA, Malaysia. Her research interests are in synthesizing and fabricating advance semiconductor materials (group IV, III-V)) and devices utilizing low cost techniques. Her PhD research work entittle: Studies of Ge nanostructures Studies of $\mathrm{Si}$ and Ge Nanostructures Synthesized By Electrochemical and Plasma Assisted Techniques For Sensing Applications. She is author and co-author of over 20 scientific publications in this field. She is a companion member of Institute of Engineer's Malaysia (IEM). 